\title{
The Hormonal Study of the Thyroid Gland of Male and Female Chabro Chicken Reared in Summer and Winter Seasons
}

\author{
Amit Singh Vishen ${ }^{1}$, Varsha Gupta ${ }^{1}$, M. M. Farooqui ${ }^{1}$, Renu $\operatorname{Yadav}^{1}$, \\ R. K. Gupta ${ }^{2 *}$ and Anand Singh ${ }^{1}$ \\ ${ }^{1}$ Department of Veterinary Anatomy, College of Veterinary and Animal Sciences, U.P., India \\ Pandit Deen Dayal Upadhyaya Pashu Chikitsa Vigyan Vishwavidyalaya Evam Go- \\ Anusandhan Sansthan, (DUVASU), Mathura - 281001, Uttar Pradesh, India \\ ${ }^{2}$ Department of Veterinary Pathology, College of Veterinary Science and Animal Husbandry, \\ ANDUAT, Kumarganj, Ayodhya-224229, Uttar Pradesh, India \\ *Corresponding author
}

\section{A B S T R A C T}

\section{Keywords}

Thyroid gland, Chabro chicken, Hormone, Season

Article Info

Accepted:

15 November 2019

Available Online:

10 December 2019
The present study was conducted on thyroid gland of eight to ten weeks old 12 apparently healthy Chabro chickens procured from Poultry Farm, DUVASU, Mathura. The birds were divided into two groups consist of six chickens in each group (three male and three female) reared in summer and winter seasons. The serum concentration of $\mathrm{T}_{3}, \mathrm{~T}_{4}$ and $\mathrm{TSH}$ hormone was measured in both groups. In summer the concentration of $\mathrm{T}_{3}$ was higher in male than female but $\mathrm{T}_{4}$ concentration was higher in female chabro. In winter the concentrations of $\mathrm{T}_{3}$ and $\mathrm{T}_{4}$ was higher in female in comparison to male chabro. The concentration of $\mathrm{T}_{3}, \mathrm{~T}_{4}$ and $\mathrm{TSH}$ was higher in winter season than summer season. Increased activity of active follicles in winter season was responsible for higher concentration of thyroid hormones in the same season.

\section{Introduction}

Thyroid is a bilobed structure situated on either side of trachea. It is the only gland in the body of both mammals and birds that stores hormone in its inactive form. In birds, thyroid gland controls the basal metabolic rate, differentiation and development of the central nervous system, development and growth of muscles and bones, control of reproduction and integumentary development including feathering. The thyroid hormones are primarily involved in energy production by increasing the metabolic rate. This increase in energy production is to the greatest extent manifested as heat production. Secretion of 
TSH and T4 of thyroid gland play an important role in maintenance of body temperature in hot and cold seasons in fowl (Hahn et al., 1965).

\section{Materials and Methods}

The present study was conducted on thyroid gland of eight to ten weeks old 12 apparently healthy Chabro chickens procured from Poultry Farm, DUVASU, Mathura. The birds were divided into two groups consist of six chickens in each group (three male and three female) reared in summer and winter seasons. Serum concentration of T3, T4 and TSH were determined by Chemiluminescence Immuno Assay technology by using Bayer Centaur Abott architect kits supplied by Garrytown, New York. The serum concentration of T3, T4 and TSH were detected for 6 chickens (3 males, 3 females) in each season i.e. summer ( 6 chickens) and winter ( 6 chickens).

\section{Results and Discussion}

In summer the concentration of $\mathrm{T}_{3}$ was higher in male $(80 \pm 7.00 \mathrm{ng} / \mathrm{dL})$ than female $(72.67 \pm$
$8.25 \mathrm{ng} / \mathrm{dL}$ ) and $\mathrm{T}_{4}$ concentration was higher in female chabro $(0.17 \pm 0.07 \mu \mathrm{g} / \mathrm{dL})$ than male chabro chicken $(0.1 \pm 0.00 \mu \mathrm{g} / \mathrm{dL})$. The thyroid stimulating hormone (TSH) concentration was equal in both male and female $(0.01 \pm 0.00 \mu \mathrm{IU} / \mathrm{ml})$ (Table 1). In winter the concentration of $\mathrm{T}_{3}(122.67 \pm 23.62$ $\mathrm{ng} / \mathrm{dL})$ and $\mathrm{T}_{4}(0.77 \pm 0.03 \mu \mathrm{g} / \mathrm{dL})$ was higher in female in comparison to male chabro $\left(\mathrm{T}_{3}\right.$ was $109.00 \pm 25.74 \mathrm{ng} / \mathrm{dL}$ and $\mathrm{T}_{4}$ was $0.63 \pm$ $0.18 \mu \mathrm{g} / \mathrm{dL}$ ) but TSH concentration was slightly higher in male chabro chicken $(0.05 \pm$ $0.00 \mu \mathrm{IU} / \mathrm{ml})$ in comparison to female chabro $(0.04 \pm 0.01 \mu \mathrm{IU} / \mathrm{ml}) \quad($ Table 1$)$. The concentration of $T_{3}$ and $T_{4}$ was $76.33 \pm 5.11$ $\mathrm{ng} / \mathrm{dL}$ and $0.13 \pm 0.03 \mu \mathrm{g} / \mathrm{dL}$, respectively in summer. The respective cofigures in winter were $115.83 \pm 15.92 \mathrm{ng} / \mathrm{dL}$ and $0.70 \pm 0.09$ $\mu \mathrm{g} / \mathrm{dL}$ (Table 2). Sinha et al., (2016) in eight weeks old Pati ducks reported the $\mathrm{T}_{3}$ and $\mathrm{T}_{4}$ concentration as $2.593 \pm 0.006 \mathrm{nmol} / \mathrm{L}$ and $46.708 \pm 0.401 \mathrm{nmol} / \mathrm{L}, \quad$ respectively (irrespective of season). The concentrations of $\mathrm{T}_{3}, \mathrm{~T}_{4}$ and TSH were higher in winter season than summer season (Table 2).

Table.1 Average values (Mean $\pm \mathrm{SE}$ ) for plasma concentration of $\mathrm{T}_{3}, \mathrm{~T}_{4}$ and $\mathrm{TSH}$ hormones in male and female chabro chickens reared in summer and winter seasons

\begin{tabular}{|c|c|c|c|c|c|c|c|c|c|}
\hline & & $\underset{(\mathbf{n}=\mathbf{3})}{\mathbf{M}_{1}}$ & $\begin{array}{c}\mathbf{M}_{2} \\
(\mathrm{n}=3)\end{array}$ & $\begin{array}{c}\mathbf{M}_{\mathbf{3}} \\
(\mathbf{n}=\mathbf{3})\end{array}$ & MEAN & $\begin{array}{c}\mathbf{F}_{1} \\
(\mathbf{n}=\mathbf{3})\end{array}$ & $\begin{array}{c}\mathbf{F}_{2} \\
(\mathrm{n}=\mathbf{3})\end{array}$ & $\begin{array}{c}\mathbf{F}_{3} \\
(\mathrm{n}=\mathbf{3})\end{array}$ & MEAN \\
\hline \multirow[t]{3}{*}{ SUMMER } & $\mathrm{T}_{3}$ & 78 & 69 & 93 & $80 \pm 7$ & 76 & 57 & 85 & $72.67 \pm 8.25$ \\
\hline & $\mathrm{T}_{4}$ & 0.1 & 0.1 & 0.1 & $0.1 \pm 0.00$ & 0.1 & 0.3 & 0.1 & $0.17 \pm 0.07$ \\
\hline & $\begin{array}{l}\text { TS } \\
\mathrm{H}\end{array}$ & 0.01 & 0.01 & 0.01 & $0.01 \pm 0.00$ & 0.02 & 0.01 & 0.01 & $0.01 \pm 0.00$ \\
\hline \multirow[t]{3}{*}{ WINTER } & $\mathrm{T}_{3}$ & 106 & 66 & 155 & $\begin{array}{c}109.00 \pm \\
25.74\end{array}$ & 135 & 156 & 77 & $122.67 \pm 23.62$ \\
\hline & $\mathrm{T}_{4}$ & 0.7 & 0.9 & 0.3 & $0.63 \pm 0.18$ & 0.7 & 0.8 & 0.8 & $0.77 \pm 0.03$ \\
\hline & $\begin{array}{l}\text { TS } \\
\mathrm{H}\end{array}$ & 0.06 & 0.05 & 0.05 & $0.05 \pm 0.00$ & 0.04 & 0.03 & 0.06 & $0.04 \pm 0.01$ \\
\hline
\end{tabular}


Table.2 Average values (Mean $\pm \mathrm{SE}$ ) for plasma concentration of $\mathrm{T}_{3}, \mathrm{~T}_{4}$ and TSH hormones in chabro chickens (both male and female) reared in summer and winter seasons

\begin{tabular}{|c|c|c|c|}
\hline & Summer & Winter & p value \\
\hline $\mathbf{T}_{\mathbf{3}}(\mathbf{n g} / \mathbf{d l})$ & $76.33 \pm 5.11$ & $115.83 \pm 15.92$ & 0.067 \\
\hline $\mathbf{T}_{\mathbf{4}}(\boldsymbol{\mu g} / \mathbf{d l})$ & $0.13 \pm 0.03^{\mathbf{a}}$ & $0.70 \pm 0.09^{\mathbf{b}}$ & 0.001 \\
\hline $\mathbf{T S H}(\boldsymbol{\mu I U} / \mathbf{m l})$ & $0.01 \pm 0.00^{\mathbf{a}}$ & $0.05 \pm 0.00^{\mathbf{b}}$ & 0.001 \\
\hline
\end{tabular}

NOTE: Superscript $\mathbf{a}, \mathbf{b}$... shows significant change in values between summer and winter season

This finding was in accordance with Reineke and Turner (1945) in chicks, Turner (1948) in Old White Leghorn and Beyzai and Adibmoradi (2010) in ostrich. Prakash and Rathor (1991) in goat, Tuckova et al., (1995) in German Shepherd and Dachshund dogs, Shehata et al., (1998) in Newzealand white rabbits, Rasooli et al., (2004) in cattle, Rajeb et al., (2011) in the dromedary, Lalsangpuii et al., (2015) in Mizoram strain adult female mithun and Chakraborty et al., (2017) in crossbred pigs reported that the high temperature decreases the thyroid hormones serum level and the low temperature increases thyroid hormones serum level. The mechanism by which the body adjust the temperature variation involves the increase secretion of TSH and $\mathrm{T}_{3}$ during period of cold environment and decreases during hot environment (Hahn et al., 1965).

It was concluded that the concentration of $\mathrm{T}_{3}$, $\mathrm{T}_{4}$ and TSH was higher in winter season than summer season due to increased activity of active follicles in winter season.

\section{References}

Beyzai, A.R., and Adibmoradi, M. 2010. Histological and Histometrical changes of ostrich thyroid gland during summer and winter seasons in Tehran, Iran. African Journal of Biotechnology, 10 (8): 1496-1501.

Chakraborty, A., Baruah, A., Sarmah, B.C., et al., 2017. Thyroid response to Temperature Humidity Index in crossbred pigs supplemented with antioxidants during Summer and Winter. Advances in Animal and Veterinary Sciences, 5 (6): 271-275.

Hahn, D.W., Ishibashi, T. and Turner, C.W. 1965. Alteration of Thyroid Hormone Secretion Rate in Fowls Changed from a Cold to a Warm Environment. Missouri Agriculture Experiment Station Journal Series No. 2955.

Lalsangpuii, Ali, M.A., Devi, L.I., Behera, P and Ralte, L. 2015. Effect of age and season on the thyroid hormone activity of Mizoram strain female mithun (Bos frontalis). Veterinary World, 8 (12): 1375-1378.

Prakash, P and Rathor, V.S.1991. Seasonal variation in blood serum profile of triiodothyronine and thyroxin in goat. Indian Journal of Animal Science, 61 (12): 1311-1312.

Rajeb, A., Amara, A., Rekik, M., Rezeigui, H. and Crespeau, F. 2011. Histomorphometry and hoemone secretion of thyroid gland of the dromedary (Camelus dromedarius). Journal of Camelid Science, 4: 10-22.

Rasooli, A., Nouri, M., Khadjeh, G.H. and Rasekh, A. 2004. The influences of seasonal variations on thyroid activity and some biochemical parameters of cattle. Iranian Journal of Veterinary Research, 5 (2): 1383-1391.

Reineke, E.P. and Turner, C.W. 1945. Seasonal rhythms in the thyroid hormone secretion of the chick. Poultry science, 24: 499. 
Shehata, A.S., Sarhan, M.E.I. and Gendy, K.M. 1998. Digestibility thyroid function and Growth performance of New Zealand white rabbits as affected by season of the year and age. Egyptian Journal of Rabbit Sciences, 8 (2):141-156.

Sinha, S., Sarma, M. and Choudhury, K.B.D. 2016. Histomorphology of Thyroid gland and Thyroid hormonal changes in Pati ducks (anas platyrhynchos domesticus) of Assam with age. Theriogenology Insight, 6 (1): 19-25.

Tuckova, M., Fialkovicova, M., Baranova, D., Bekeova, E., Kozak, M. and Palenik, L. 1995. Effects of season on thyroid hormone concentrations in the blood serum of German Shepherds and Dachshunds and their health status. Veterinary Medicine, 40 (8): 249-252.

Turner, C.W. 1948. Effects of age and season on the thyroxin secretion rate of white leghorn hens. Poultry Science, 27: 146.

\section{How to cite this article:}

Amit Singh Vishen, Varsha Gupta, M. M. Farooqui, Renu Yadav, R. K. Gupta and Anand Singh. 2019. The Hormonal Study of the Thyroid Gland of Male and Female Chabro Chicken Reared in Summer and Winter Seasons. Int.J.Curr.Microbiol.App.Sci. 8(12): 1700-1703. doi: https://doi.org/10.20546/ijcmas.2019.812.204 